\title{
Rapid biological oxidation of methanol in the tropical Atlantic: significance as a microbial carbon source
}

\author{
J. L. Dixon, R. Beale, and P. D. Nightingale \\ Plymouth Marine Laboratory, Prospect Place, West Hoe, Plymouth, Devon, PL1 3DH, UK \\ Received: 12 April 2011 - Published in Biogeosciences Discuss.: 18 April 2011 \\ Revised: 1 September 2011 - Accepted: 12 September 2011 - Published: 23 September 2011
}

\begin{abstract}
Methanol is the second most abundant organic gas in the atmosphere after methane, and is ubiquitous in the troposphere. It plays a significant role in atmospheric oxidant chemistry and is biogeochemically active. Large uncertainties exist about whether the oceans are a source or sink of methanol to the atmosphere. Even less is understood about what reactions in seawater determine its concentration, and hence flux across the sea surface interface. We report here concentrations of methanol between 151-296 nM in parts of the oligotrophic North Atlantic, with corresponding microbial uptake rates between $2-146 \mathrm{nM} \mathrm{d}^{-1}$, suggesting turnover times as low as 1 day (1-25 days) in surface waters of the oligotrophic tropical North East Atlantic. Methanol is mainly ( $\geq 97 \%$ ) used by microbes for obtaining energy in oligotrophic regions, which contrasts with shelf and coastal areas where between $20-50 \%$ can be used for cell growth. Comparisons of microbial methanol oxidation rates with parallel determinations of bacterial leucine uptake suggest that methanol contributes on average $13 \%$ to bacterial carbon demand in the central northern Atlantic gyre (maximum of $54 \%$ ). In addition, the contribution that methanol makes to bacterial carbon demand varies as a power function of chlorophyll a concentrations; suggesting for concentrations $<0.2 \mu \mathrm{g} 1^{-1}$ that methanol can make a significant contribution to bacterial carbon demand. However, our low air to sea methanol flux estimates of $7.2-13 \mu \mathrm{mol} \mathrm{m}^{-2} \mathrm{~d}^{-1}$ suggest that the atmosphere is not a major methanol source. We conclude that there must be a major, as yet unidentified, in situ oceanic methanol source in these latitudes which we suggest is sunlight driven decomposition of organic matter.
\end{abstract}

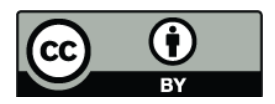

Correspondence to: J. L. Dixon (jod@pml.ac.uk)

\section{Introduction}

Methanol is the second most abundant organic gas in the atmosphere after methane (Jacob et al., 2005), and is ubiquitous in the atmosphere (Singh et al., 2000) where it is a significant source of tropospheric CO through photochemical oxidation (Duncan et al., 2007). It plays a significant role in atmospheric oxidant chemistry where, for example, it reacts directly with hydroxyl radicals forming products that are a source of formaldehyde, hydrogen radicals, and ozone (Heikes et al., 2002). In cloud water, methanol photochemical reactions are thought to produce formic acid contributing to cloud and rainwater acidity (Heikes et al., 2002), although Jacob (1986) argues that in-cloud formic acid production is too slow to have a significant affect on $\mathrm{pH}$. There is a large uncertainty in the atmospheric methanol budget, with global sources from plant growth and decay, biomass burning, urban emissions and atmospheric production ranging between 122-350 $\mathrm{Tg} \mathrm{a}^{-1}$ (Singh et al., 2000; Galbally and Kirstine, 2002; Heikes et al., 2002; Tie et al., 2003; Jacob et al., 2005; Millet et al., 2008). The role of the oceans as a source (Singh et al., 2000, 2001; Heikes et al, 2002; Mao et al., 2006) or sink (Heikes et al., 2002; Singh et al., 2003; Carpenter et al., 2004; Williams et al., 2004; Jacob et al., 2005; Mao et al., 2006; Sinha et al., 2007; Millet et al., 2008) of methanol in also uncertain, and has been hampered by the analytical difficulties in reliably determining methanol concentrations in seawater due to its high solubility. The first flux estimates calculated using in situ surface methanol concentrations report a mean flux of $66 \pm 267 \mu \mathrm{mol} \mathrm{m} \mathrm{m}^{-2} \mathrm{~d}^{-1}$ from the atmosphere to the ocean in the tropical North Atlantic (Williams et al., 2004). Methylotrophic bacteria, who by definition, must survive on one carbon (C1) compounds like methanol (Murrell and McDonald, 2000), have been found in nearshore coastal zones (Neufeld et al., 2007, 2008; Giovannoni et al., 2008) and in oceanic regions (Dixon et al., 2011). In addition, molecular studies have suggested that a diverse range of

Published by Copernicus Publications on behalf of the European Geosciences Union. 
prokaryotes and eukaryotes are thought able to use methanol for growth (Murrell and McDonald, 2000).

Methanol, and other oxygenated volatile organic compounds form part of the dissolved organic carbon (DOC) pool. Dissolved organic carbon production by phytoplankton is believed to be the primary organic carbon source for marine bacteria. However for oligotrophic waters, particularly those from the tropical Atlantic, bacterial carbon demand often exceeds dissolved organic carbon produced by phytoplankton (e.g. Agustí et al., 2001; Duarte et al., 2001; Hoppe et al., 2002; Gasol et al., 2009 and references therein) indicating that additional sources are needed to sustain bacterial production in nutrient depleted areas (e.g. Morán et al., 2007; López-Sandoval et al., 2011)

We have modified a radiochemical technique to quantify microbial methanol uptake rates in seawater, and have previously reported biological methanol oxidation rates of 2.1$8.4 \mathrm{nmol}^{-1} \mathrm{~d}^{-1}$ i.e. loss rate, largely in coastal and shelf areas (Dixon et al., 2011). We also previously estimated microbial methanol turnover times of 12-24 days in coastal and shelf stations (Dixon et al., 2011).

The aim of this research in nutrient limited tropical waters of the North East Atlantic was to: (1) make the first combined measurements of microbial-mediated losses of methanol from seawater together with in situ methanol concentrations and (2) to investigate whether methanol could be a significant compound in meeting bacterial carbon demand.

\section{Methods}

\subsection{Sampling}

Sampling was mainly conducted at a series of stations in the tropical North Atlantic during two research cruises aboard the RRS James Cook (Atlantic Meridional transect, AMT19) and RRS Discovery (Surface Ocean Lower Atmosphere Study: Investigation of the near surface production of Iodocarbons, D325). For comparison purposes, stations sampled west of the Iberian Peninsula and European shelf waters aboard RRS Discovery (Surface Ocean Lower Atmosphere Study: Deep Ocean Gas Exchange Experiment II, D320) and from a coastal western English Channel site (L4, Western Channel Observatory) are also included (Fig. 1).

\subsection{Microbial methanol oxidation and uptake into particles}

We incubated surface seawater samples with nanomolar concentrations of ${ }^{14} \mathrm{C}$ labelled methanol $\left({ }^{14} \mathrm{CH}_{3} \mathrm{OH}\right)$ and determined both uptake into particles and oxidation to $\mathrm{CO}_{2}$ (Dixon et al., 2011), which we interpret as microbial cellular incorporation (cell growth, $G$ ) and energy use $(E)$, respectively. For full experimental details please refer to Dixon et al. (2011). In brief, seawater samples were treated with approximately $10 \mathrm{nM}$ final added concentration of ${ }^{14} \mathrm{CH}_{3} \mathrm{OH}$,

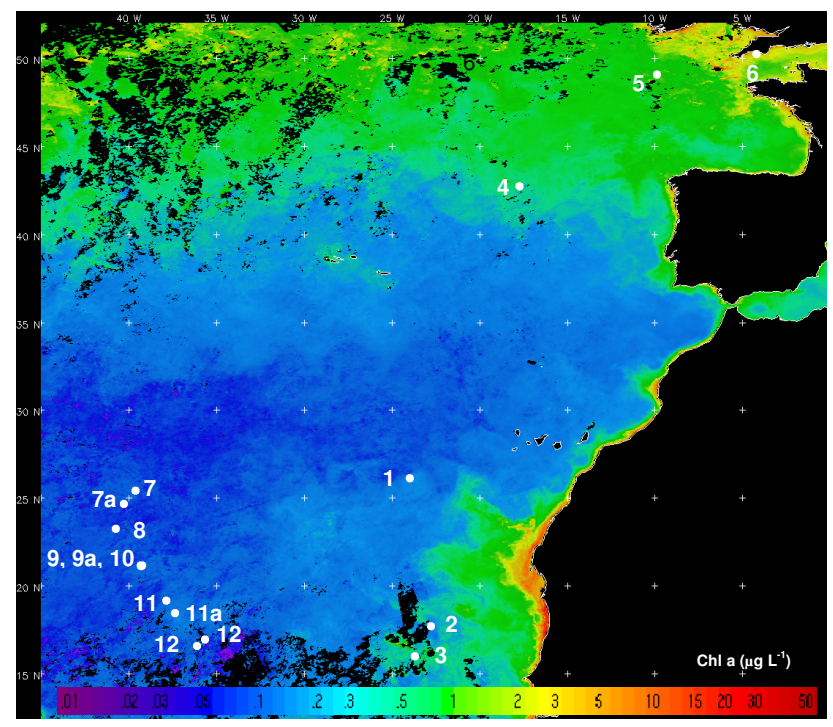

Fig. 1. Sample locations and the composite chlorophyll- $a$ image for October 2009 from the MODIS sensor on the NASA Aqua satellite (courtesy of NERC Earth Observation Data Acquisition and Analysis Service (NEODAAS) at Plymouth Marine Laboratory, http://www.neodaas.ac.uk).

and were always $<1 \%$ of the sample volume. This concentration of radiolabel was chosen as a compromise between obtaining sufficient sample counts within the linear period of label incorporation, and not wishing to provide excess methanol which could artificially stimulate microbial uptake or oxidation rates. An addition of $10 \mathrm{nM}^{14} \mathrm{CH}_{3} \mathrm{OH}$ final concentration typically represented between 3-20\% of in situ concentrations. The period of linear incorporation of the labelled methanol was typically up to $18 \mathrm{~h}$, and was routinely tested for uptake into particles and oxidation. Kinetic experiments typically show multiphasic behaviour for methanol uptake into particles, which suggests that for added ${ }^{14} \mathrm{CH}_{3} \mathrm{OH}$ concentrations $\leq 20-30 \mathrm{nM}$, bacterial transport processes dominate, whereas at higher concentrations incorporation due to diffusion across cell membranes is likely to dominate (Dixon et al., 2011). We generally incubated oxidation samples for $2-3 \mathrm{~h}$, and uptake onto particles for 3-9 $\mathrm{h}$ (to ensure sufficient counts).

The data is reported as apparent rate constants, $k\left(\mathrm{~h}^{-1}\right)$ calculated from a ratio of the sample ${ }^{14} \mathrm{C}$ counts (from the particles on the filter or from the precipitate which contains the captured ${ }^{14} \mathrm{CO}_{2}$ as $\mathrm{Sr}^{14} \mathrm{CO}_{3}, \mathrm{nCi} \mathrm{ml}^{-1} \mathrm{~h}^{-1}$ ) divided by total ${ }^{14} \mathrm{CH}_{3} \mathrm{OH}$ added to the sample $\left(\mathrm{nCi} \mathrm{ml}^{-1}\right)$. All rate constants were corrected by subtracting killed sample (TCA, $5 \%$ final concentration) counts. Evaluation of control samples suggests that $\leq 1.8 \%$ of the added ${ }^{14} \mathrm{CH}_{3} \mathrm{OH}$ is counted in the resultant precipitate (for determining oxidation) and $\leq 0.3 \%$ is recovered on the filters. Methanol oxidation or uptake rates were calculated from the product of $k$ multiplied by the in situ concentration of methanol. This was 
determined independently by membrane inlet-proton transfer reaction mass spectrometry (MI PTR-MS), which was calibrated using spiked seawater standard additions (Beale et al., 2011). The relative error in $k(n=3)$ was $\leq 5 \%$, and for in situ methanol concentrations was $7 \%(n=11)$, giving a combined estimated error of $\leq 12 \%$ for methanol oxidation rates.

\subsection{Community composition and chlorophyll- $a$ concentraion}

We also carried out parallel determinations of the concentration of chlorophyll- $a$ (chl), numbers of heterotrophic bacteria (BN), Synechococcus (Syns) and Prochlorococcus spp. (Pros). The numbers of bacterioplankton cells were determined by flow cytometry on SYBR Green I DNA-stained cells from $1.8 \mathrm{ml}$ seawater samples fixed in paraformaldehyde (5\%, final concentration). Numbers of Prochlorococcus spp. and Synechococcus spp. were analysed on unstained samples by flow cytometry. Surface concentrations of chlorophyll- $a$ were estimated using a composite AquaMODIS chlorophyll- $a$ remotely sensed image for stations 4 and 5, as unfortunately the continuous surface fluorometer onboard the ship (D320) was not working correctly. For all other stations chlorophyll- $a$ samples were determined by fluorometric analysis of acetone-extracted pigments (HolmHansen et al., 1965).

\subsection{Primary and bacterial production}

Primary production (PP) was estimated using the standard method of ${ }^{14} \mathrm{C}$-bicarbonate incorporation (e.g. Joint and Pomroy, 1993; Dixon et al., 2006; Dixon, 2008) except that for stations 1-3 samples were incubated for approximately $6 \mathrm{~h}$ (between 09:00-15:00 LT) and for stations 7-12 samples were incubated from dawn to dusk. Heterotrophic bacterial production rates were determined by measuring the incorporation of ${ }^{3} \mathrm{H}$-leucine ( $20 \mathrm{nM}$ final concentration) into bacterial protein synthesis on $1.7 \mathrm{ml}$ seawater samples following the method of Smith and Azam (1992). The relative error based on 3 replicates was on average $7.5 \%$.

\subsubsection{Leucine to carbon conversion factors}

Bacterial production (BP) was calculated from the leucine incorporation rate using an average empirically derived conversion factor of $0.73 \mathrm{kgC} \mathrm{mol} \mathrm{leu}^{-1}$. Published conversion factors for the surface waters of the Atlantic Ocean range between 0.17-1.55 $\mathrm{kgC} \mathrm{mol} \mathrm{leu}^{-1}$ (Agustí et al., 2001; Zubkov et al., 2001; Hoppe et al., 2002; Gasol et al., 2009; AlonsoSáez et al., 2007; Martínez-García et al., 2010), but measurements made close to our sampling locations, depths and time of year are typically in the middle of this range (Barbosa et al., 2001; Morán et al., 2002, 2004; Dixon, 2008; Calvo-Díaz and Morán, 2009).

\subsection{Bacterial carbon demand}

Bacterial carbon demand (BCD) is the total amount of carbon required by bacteria for both production and respiration (Robinson, 2008). Bacterial production was determined as detailed above. Bacterial respiration (BR) was calculated from production where $\mathrm{BR}=3.69 \mathrm{BP}^{0.58}$ (Robinson, 2008). Bacterial growth efficiency (BGE) was calculated in two different ways; firstly using production (BP) and respiration (BR) estimates, and secondly using chlorophyll- $a$ concentrations (Table 1). BCD was calculated by dividing bacterial production (BP) by the average of the two estimates of BGE.

\section{Results}

\subsection{Methanol oxidation and uptake in relation to biological production parameters}

\subsubsection{Diel stations in the NE Atlantic}

We undertook three diel experiments using drogued surface drifters in the tropical North Atlantic during November/December 2007 (Fig. 2). Hourly surface $(<10 \mathrm{~m})$ measurements of $G$ and $E$ were determined for at least $24 \mathrm{~h}$ at stations of contrasting microbial productivity (Stations 1-3 Tables 1 and 2). At the most oligotrophic station (Stn 1) where the concentrations of nitrate plus nitrite $(\mathrm{N})$ and phosphate $(\mathrm{P})$ were 9 and $<5 \mathrm{nM}$ respectively (Table 1 ), chl and average rates of $\mathrm{PP}, \mathrm{BP}$ and $\mathrm{BN}$ were very low. However, we found the highest average rate of microbial methanol oxidation of $5 \mathrm{nmol}^{-1} \mathrm{~h}^{-1}$ (range of 3.2-6.1 $\mathrm{nmoll}^{-1} \mathrm{~h}^{-1}$, Table 2) with an estimated turnover as low as 1 day (Table 2). The corresponding microbial uptake rates into particles were low with an average $E: G$ of 360 . This suggests that more than $99 \%$ of the methanol was used by the microbes as an energy supply rather than for growth at this station. There was higher microbial activity at station 2 despite very low concentrations of nutrients $(\mathrm{N}=1 \mathrm{nM}, \mathrm{P}=67 \mathrm{nM}$, Table 1$)$. The average rate of methanol oxidation was approximately five fold lower, with a higher uptake into particles than station 1, giving a $E: G$ of 32 (Table 2). This suggests that relatively more methanol was used here as a carbon source for microbial growth. Station 3 was located within the Cape Verde archipelago, and had slightly elevated, but still nanomolar nutrient concentrations $(\mathrm{N}=203 \mathrm{nM}, \mathrm{P}=96 \mathrm{nM}$, Table 1) with the highest microbial biomass and production rates of the diel experiments. The average rate of methanol oxidation was the same as Stn 2 (Table 2). Methanol turnover times for both stations 2 and 3 were on average 6-7 times longer than for the most oligotrophic station. However, the highest methanol uptake into particles was observed at station 3 resulting in an average $E: G$ ratio of 12 .

Diel patterns in methanol oxidation rates varied consistently during all experiments: typically, $E$ was highest at or just before dawn and decreased throughout the day until 
Table 1. Nutrients, bacterial production, respiration, growth efficiency and carbon demand from surface $(\leq 10 \mathrm{~m})$ waters of the eastern North Atlantic.

\begin{tabular}{|c|c|c|c|c|c|c|c|c|c|}
\hline $\begin{array}{l}\text { Sampling date } \\
\text { (description) }\end{array}$ & No & $\begin{array}{l}\mathrm{NO}_{3}+ \\
\mathrm{NO}_{2} \\
(\mathrm{nM})^{\mathrm{g}}\end{array}$ & $\begin{array}{l}\mathrm{PO}_{4} \\
(\mathrm{nM})^{\mathrm{g}}\end{array}$ & $\begin{array}{l}\text { Bacterial production } \\
\left(\text { pmol Leu } 1^{-1} \mathrm{~h}^{-1}\right)\end{array}$ & $\begin{array}{l}\mathrm{BP}^{\mathrm{a}} \\
\left(\mu \mathrm{gC} 1^{-1} \mathrm{~h}^{-1}\right)\end{array}$ & $\begin{array}{l}\mathrm{BR}^{\mathrm{b}} \\
\left(\mu \mathrm{gC} 1^{-1} \mathrm{~h}^{-1}\right)\end{array}$ & $\begin{array}{l}\mathrm{BGE}^{\mathrm{c}} \\
(\mathrm{BP} \text { and } \mathrm{BR})\end{array}$ & $\begin{array}{l}\mathrm{BGE}^{\mathrm{d}} \\
(\mathrm{Chl}-a)\end{array}$ & $\begin{array}{l}\text { Bacterial car- } \\
\text { bon demand } \\
\left(\mu \mathrm{gC} 1^{-1} \mathrm{~h}^{-1}\right)\end{array}$ \\
\hline \multicolumn{10}{|l|}{ North Atlantic } \\
\hline $\begin{array}{l}12 \mathrm{Dec} 2007 \\
\left(26^{\circ} \mathrm{N} 24^{\circ} \mathrm{W}\right)\end{array}$ & 1 & 9 & $<5$ & $\begin{array}{l}2.7 \\
(0.8-4.7)^{\mathrm{f}}\end{array}$ & 0.002 & 0.10 & 0.02 & 0.03 & 0.10 \\
\hline $\begin{array}{l}18 \text { Nov } 2007 \\
\left(18^{\circ} \mathrm{N} 23^{\circ} \mathrm{W}\right)\end{array}$ & 2 & 1 & 67 & $\begin{array}{l}19.7 \\
(9.9-32)^{\mathrm{f}}\end{array}$ & 0.014 & 0.32 & 0.04 & 0.04 & 0.34 \\
\hline $\begin{array}{l}29 \text { Nov } 2007 \\
\left(16^{\circ} \mathrm{N} 24^{\circ} \mathrm{W}\right)\end{array}$ & 3 & 203 & 96 & $64.9(36-118)^{\mathrm{f}}$ & 0.047 & 0.63 & 0.07 & 0.05 & 0.79 \\
\hline $\begin{array}{l}1 / 4 / 6 \text { Jul } 2007 \\
\left(42^{\circ} \mathrm{N} 16-18^{\circ} \mathrm{W}\right)\end{array}$ & 4 & nd & nd & $\begin{array}{l}9 \\
(3.6-14)\end{array}$ & 0.007 & 0.20 & 0.03 & 0.05 & 0.16 \\
\hline \multicolumn{10}{|l|}{ Shelf Break } \\
\hline $\begin{array}{l}17 \mathrm{Jun} 2007 \\
\left(49^{\circ} \mathrm{N} 10^{\circ} \mathrm{W}\right)\end{array}$ & 5 & nd & nd & 47.7 & 0.035 & 0.53 & 0.06 & 0.09 & 0.46 \\
\hline \multicolumn{10}{|l|}{ Coastal (L4) } \\
\hline $\begin{array}{l}6 \text { Jun } 2006 \\
\left(50^{\circ} \mathrm{N} 4^{\circ} \mathrm{W}\right)\end{array}$ & 6 & 270 & 150 & 21.4 & 0.016 & 0.33 & 0.06 & 0.16 & 0.15 \\
\hline North Atlantic & & $(\mu \mathrm{M})$ & $(\mu \mathrm{M})$ & & & & & & \\
\hline $\begin{array}{l}27 \text { Oct } 2009 \\
\left(25^{\circ} \mathrm{N} 40^{\circ} \mathrm{W}\right)\end{array}$ & 7 & $<0.02$ & $<0.02$ & 4.3 & 0.003 & 0.13 & 0.02 & 0.02 & 0.14 \\
\hline$\left(24^{\circ} \mathrm{N} 40^{\circ} \mathrm{W}\right)$ & $7 \mathrm{a}$ & $<0.02$ & $<0.02$ & 4.8 & 0.004 & 0.14 & 0.02 & 0.03 & 0.13 \\
\hline $\begin{array}{l}28 \text { Oct } 2009 \\
\left(23^{\circ} \mathrm{N} 41^{\circ} \mathrm{W}\right)\end{array}$ & 8 & $<0.02$ & $<0.02$ & 7.9 & 0.006 & 0.19 & 0.03 & 0.03 & 0.19 \\
\hline $\begin{array}{l}29 \text { Oct } 2009 \\
\left(21^{\circ} \mathrm{N} 39^{\circ} \mathrm{W}\right)\end{array}$ & 9 & $<0.02$ & $<0.02$ & 4.8 & 0.004 & 0.14 & 0.02 & 0.03 & 0.13 \\
\hline$\left(21^{\circ} \mathrm{N} 39^{\circ} \mathrm{W}\right)$ & $9 \mathrm{a}$ & $<0.02$ & $<0.02$ & 5.0 & 0.004 & 0.14 & 0.03 & 0.04 & 0.11 \\
\hline $\begin{array}{l}30 \text { Oct } 2009 \\
\left(21^{\circ} \mathrm{N} 39^{\circ} \mathrm{W}\right)\end{array}$ & 10 & $<0.02$ & $<0.02$ & 10.4 & 0.008 & 0.22 & 0.03 & 0.03 & 0.24 \\
\hline $\begin{array}{l}31 \text { Oct } 2009 \\
\left(19^{\circ} \mathrm{N} 38^{\circ} \mathrm{W}\right)\end{array}$ & 11 & $<0.02$ & $<0.02$ & 6.4 & 0.005 & 0.16 & 0.03 & 0.03 & 0.16 \\
\hline$\left(18^{\circ} \mathrm{N} 37^{\circ} \mathrm{W}\right)$ & $11 \mathrm{a}$ & $<0.02$ & $<0.02$ & 3.1 & 0.002 & 0.11 & 0.02 & 0.04 & 0.07 \\
\hline $\begin{array}{l}\text { 01 Nov } 2009 \\
\left(17^{\circ} \mathrm{N} 36^{\circ} \mathrm{W}\right)\end{array}$ & 12 & $<0.02$ & $<0.02$ & 10.4 & 0.008 & 0.22 & 0.03 & 0.03 & 0.24 \\
\hline$\left(16^{\circ} \mathrm{N} 35^{\circ} \mathrm{W}\right)$ & $12 \mathrm{a}$ & $<0.02$ & $<0.02$ & 7.8 & 0.006 & 0.18 & 0.03 & 0.04 & 0.16 \\
\hline
\end{tabular}

a Bacterial production was calculated using an empirical carbon conversion factor of $0.73 \mathrm{kgC} \mathrm{mol} \mathrm{leu}^{-1}$ which matches with literature values for the same sampling regions and season (Morán et al., 2002, 2004; Dixon, 2008; Calvo-Diaz and Morán, 2009). b Bacterial respiration was calculated from bacterial production using the relationship of $\mathrm{BR}=3.69 \mathrm{BP}^{0.58}$ (Robinson, 2008). ${ }^{\mathrm{c}}$ Bacterial growth efficiency (ratio of bacterial production to production plus respiration) has been estimated using BP and BR. ${ }^{\mathrm{d}}$ Bacterial growth efficiency estimated from in situ concentrations of chlorophyll (BGE $=1-(1 / 0.727 \times(\mathrm{chl} / \mathrm{chl}+4.08)+1.02))\left(\right.$ López-Urrutia and Morán, 2007). ${ }^{\mathrm{e}}$ Bacterial carbon demand has been calculated as BP divided by the average of BGE (BP and BR) and BGE (Chl- $a$ ). ${ }^{\mathrm{f}}$ Range found during the diel experiments where surface samples were taken approximately every hour over a $24 \mathrm{~h}$ period. $\mathrm{g}$ Nutrients were available using nano molar techniques for stations $1-3$ only, otherwise nutrient concentrations were determined using $\mu$ molar techniques only.

dusk whereupon rates slowly increased (Fig. 2a). On average, methanol oxidation rates at stations 1 and 2 were the same during light and dark hours despite the steep decrease during the day (Fig. 2a). For station 3, average rates of methanol oxidation were twice as high during the day compared to the night. This pattern is not entirely consistent with the interpretations of Sinha et al. (2007) who deduce from atmospheric methanol concentrations (after a phytoplankton bloom during a mesocosm experiment in a Norwegian fjord) that the net flux of methanol from the atmosphere to the sea was stronger at night. Our results from station 3 show higher methanol losses from surface seawater during the day; which could invoke a higher flux into the ocean from the atmosphere, if the atmosphere was the major source of methanol.

The diel patterns are not fully understood, but it is interesting that for stations 1 and 2, statistically significant relationships were observed between methanol oxidation and numbers of Syns (Stn 1: $r=0.604, n=19, P \leq 0.01$, Stn 2: $r=0.734, n=20, P \leq 0.001)$. Whilst this does not prove that Syns were oxidising methanol, it is interesting that they also uptake amino acids like methionine e.g. are not obligate phototrophs (Mary et al., 2008). Open ocean Pros also 

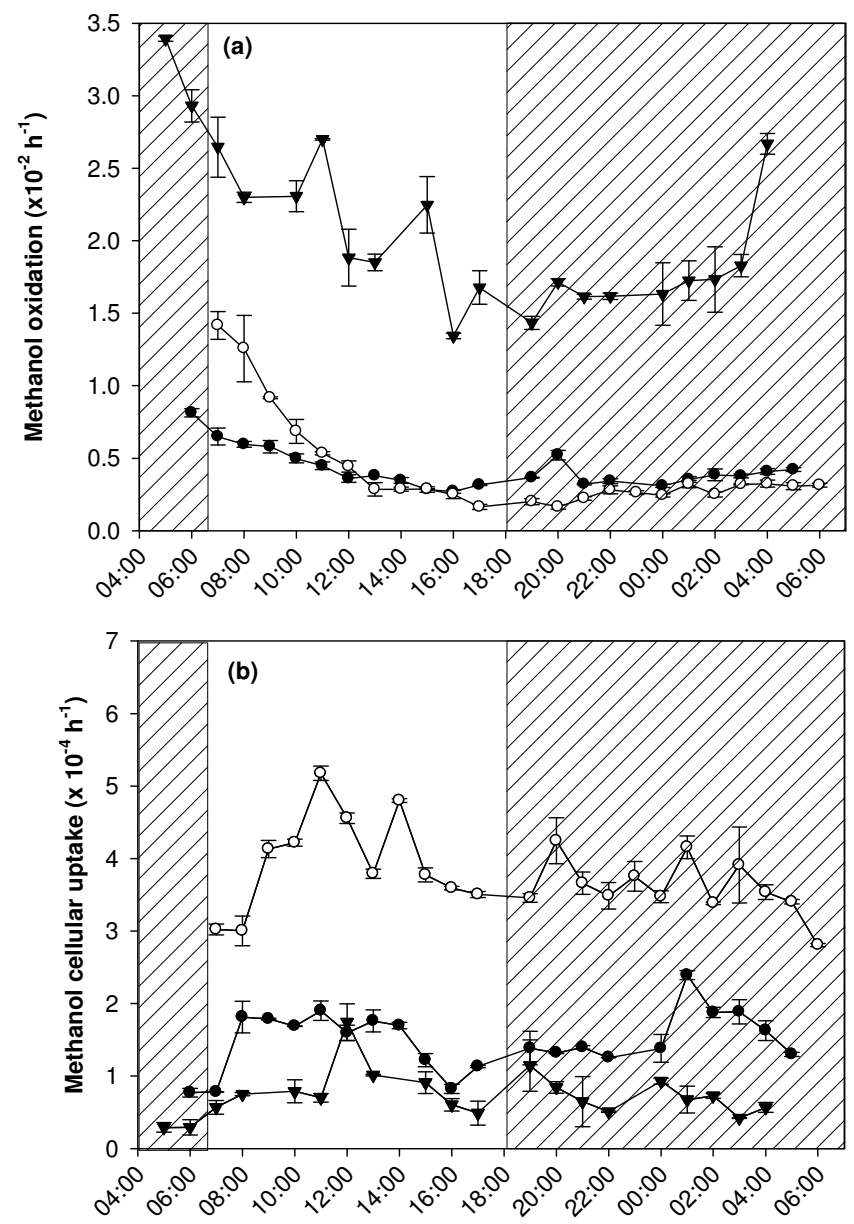

Fig. 2. Methanol oxidation (a) and uptake into particles (b) for stations $1(\boldsymbol{\nabla}), 2(\bullet)$ and $3(\circ)$. The hatched area shows night measurements and error bars represent \pm 1 standard deviation of 3 replicate samples. Time in GMT.

uptake amino acids (Zubkov et al., 2004; Mary et al., 2008) with a diel rhythmicity that has been linked to a specific cell cycle stage (Mary et al., 2008). Obvious diel trends in the microbial uptake of methanol into particles were not evident (Fig. 2b). The diel experiments may not have been truly Lagrangian, as they were tracked with drogued surface drifters. Strong wind (station 3) and tides/currents around the Cape Verde islands may have caused the drifters to separate from the waters we wished to follow over the experiment.

\subsubsection{West of the Iberian Peninsula and European shelf}

We also made surface measurements of both $G$ and $E$ off the Iberian Peninsula during July 2007 (station 4). Here chl, BP and BN were typical of mesotrophic waters. However, the lowest rates of methanol utilisation were found e.g. $0.12 \mathrm{nmoll}^{-1} \mathrm{~h}^{-1}(E: G 82)$, resulting in the longest methanol turnover estimates of 60-83 days (Table 2).
At stations 5 and 6 on the European Shelf (Fig. 1) nutrients were the highest of all stations sampled $(\mathrm{N}=270 \mathrm{nM}$, $\mathrm{P}=150 \mathrm{nM}$, for station 6 , Table 1) with corresponding elevated chl and BP (in comparison to oligotrophic open ocean stations, Table 2), methanol oxidation rate constants were intermediate, giving turnover times of 12 and 6 days, respectively. However, the highest values of methanol uptake into particles were observed in these productive waters, resulting in $E: G$ of 5 and 2 (Table 2). This suggests that for shelf seas, during biologically productive months, a higher proportion of microbial methanol uptake was used to support cellular biosynthesis (rather than as an energy source) compared to less productive oceanic regions. This is similar to the results of Kiene and Hoffmann Williams (1998), who reported that on average $47 \%$ of added methyl ${ }^{14} \mathrm{C}$ labelled glycine betaine, which is an intracellular osmolyte thought to be used by a wide variety of marine organisms, was respired as $\mathrm{CO}_{2}$ and thus used as energy in surface coastal waters.

\subsubsection{Central North Atlantic gyre (methanol oxidation only)}

We sampled stations 7-12a in the central North Atlantic gyre which at the time of sampling were not influenced by upwelling or continental inputs e.g. dust as shown by characteristic low nutrient concentrations in Table 1. We unfortunately only have micro molar nutrient concentrations from this time suggesting that concentrations of both $\mathrm{N}$ and $\mathrm{P}$ are $<0.02 \mu \mathrm{M}$. However, on a previous cruise which followed the same track during the same month in 2005 (AMT17) nanomolar determinations of nutrients suggested that $\mathrm{N}$ ranged between $5-14 \mathrm{nM}$ and $\mathrm{P}$ between $7-10 \mathrm{nM}$ i.e. oligotrophic. The concentration of chl (see Fig. 1), PP, $\mathrm{BP}$ and BN (Table 2) were also characteristically very low (Morán et al., 2002, 2004; Dixon, 2008). Microbial methanol oxidation was not as high as station 1 , but values ranged between $0.6-1.8 \mathrm{nmol}^{-1} \mathrm{~h}^{-1}$ with corresponding turnover times of 4-15 days (Table 2). These results reinforce the earlier measurements we made at station 1 and suggest that surface methanol concentrations can be removed by the microbial community in a matter of days in the oligotrophic waters of the North Atlantic.

\subsection{Methanol contribution to bacterial carbon demand}

\subsubsection{Bacterial growth}

Our bacterial leucine incorporation rates ranged between 132 pmol leu $1^{-1} \mathrm{~h}^{-1}$ for oligotrophic Atlantic waters, which is not unprecedentedly low for such waters (Morán et al., 2002, 2004; Dixon, 2008) that are away from continental inputs of dissolved organic matter during winter. Such low values have also been reported for temperate ecosystems during winter (Calvo-Díaz and Morán, 2009) when organic carbon from phytoplankton is often limited, and 
Table 2. Base parameters, methanol data and estimated contribution to bacterial carbon demand in surface waters of the North Atlantic.

\begin{tabular}{|c|c|c|c|c|c|c|c|c|c|c|c|}
\hline $\begin{array}{l}\text { Sampling date } \\
\text { (description) }\end{array}$ & No & $\begin{array}{l}\text { Temp } \\
\left({ }^{\circ} \mathrm{C}\right)\end{array}$ & $\begin{array}{l}{[\mathrm{Chl}-a]} \\
\left(\mu \mathrm{g} \mathrm{l}^{-1}\right)\end{array}$ & $\begin{array}{l}\text { Primary } \\
\text { production } \\
\left(\mathrm{mgC} \mathrm{m}^{-3} \mathrm{~h}^{-1}\right)\end{array}$ & $\begin{array}{l}\text { Bacterial } \\
\text { Numbers } \\
\left(\times 10^{5} \text { cells } \mathrm{ml}^{-1}\right)\end{array}$ & $\begin{array}{l}\text { Bacterial carbon } \\
\text { demand }^{\mathrm{a}} \\
\left(\mu \mathrm{gC} l^{-1} \mathrm{~h}^{-1}\right)\end{array}$ & $\begin{array}{l}\text { Methanol } \\
\text { concentration } \\
(\mathrm{nM})\end{array}$ & $\begin{array}{l}\text { Methanol } \\
\text { Oxidation } \\
\left(\text { nmol }^{-1} h^{-1}\right)\end{array}$ & $\begin{array}{l}\text { Turnover } \\
\text { Time }^{\mathrm{c}} \\
\text { (d) }\end{array}$ & $E: G^{\mathrm{d}}$ & $\begin{array}{l}\% \text { Carbon } \\
\text { from methanol } \\
\text { contributing to } \\
\mathrm{BCD}^{\mathrm{e}}\end{array}$ \\
\hline \multicolumn{12}{|l|}{ North Atlantic } \\
\hline $\begin{array}{l}12 \mathrm{Dec} 2007 \\
\left(26^{\circ} \mathrm{N} 24^{\circ} \mathrm{W}\right)\end{array}$ & 1 & 22.5 & 0.06 & 0.70 & $3.30 \pm 0.38$ & 0.10 & $\begin{array}{l}241^{\mathrm{f}} \\
(154-296)\end{array}$ & $\begin{array}{l}5.0 \\
(3.2-6.1)\end{array}$ & $\begin{array}{l}2 \\
(1-3)\end{array}$ & $\begin{array}{l}360 \\
(108-1162)\end{array}$ & $\begin{array}{l}54 \\
(35-66)\end{array}$ \\
\hline $\begin{array}{l}18 \text { Nov } 2007 \\
\left(18^{\circ} \mathrm{N} 23^{\circ} \mathrm{W}\right)\end{array}$ & 2 & 25.2 & 0.10 & 1.15 & $7.37 \pm 0.89$ & 0.34 & $\begin{array}{l}241^{\mathrm{f}} \\
(154-296)\end{array}$ & $\begin{array}{l}1.0 \\
(0.7-1.3)\end{array}$ & $\begin{array}{l}11 \\
(5-15)\end{array}$ & $\begin{array}{l}32 \\
(15-105)\end{array}$ & $\begin{array}{l}4 \\
(3-5)\end{array}$ \\
\hline $\begin{array}{l}29 \text { Nov } 2007 \\
\left(16^{\circ} \mathrm{N} 24^{\circ} \mathrm{W}\right)\end{array}$ & 3 & 24.8 & 0.22 & 2.1 & $8.30 \pm 1.20$ & 0.79 & $\begin{array}{l}241^{\mathrm{f}} \\
(154-296)\end{array}$ & $\begin{array}{l}1.0 \\
(0.7-1.3)\end{array}$ & $\begin{array}{l}14 \\
(3-25)\end{array}$ & $\begin{array}{l}12 \\
(4-47)\end{array}$ & $\begin{array}{l}2 \\
(1-2)\end{array}$ \\
\hline $\begin{array}{l}1 / 4 / 6 \text { Jul } 2007 \\
\left(42^{\circ} \mathrm{N} 16-18^{\circ} \mathrm{W}\right)\end{array}$ & 4 & 17.8 & $<0.2$ & - & $6.71 \pm 1.54$ & 0.16 & $\begin{array}{l}70^{\mathrm{f}} \\
(48-80)\end{array}$ & $\begin{array}{l}0.12 \\
(0.08-0.21)\end{array}$ & $\begin{array}{l}83 \\
(60-83)\end{array}$ & $\begin{array}{l}82 \\
(18-156)\end{array}$ & $\begin{array}{l}1 \\
(0.5-2)\end{array}$ \\
\hline \multicolumn{12}{|l|}{ Shelf Break } \\
\hline $\begin{array}{l}17 \text { Jun } 2007 \\
\left(49^{\circ} \mathrm{N} 10^{\circ} \mathrm{W}\right)\end{array}$ & 5 & 15.5 & 0.5 & - & - & 0.46 & $\begin{array}{l}70^{\mathrm{g}} \\
(48-80)\end{array}$ & $\begin{array}{l}0.24 \\
(0.16-0.27)\end{array}$ & 12 & 5 & $\begin{array}{l}1 \\
(0.4-1)\end{array}$ \\
\hline \multicolumn{12}{|l|}{ Coastal (L4) } \\
\hline $\begin{array}{l}6 \text { Jun } 2006 \\
\left(50^{\circ} \mathrm{N} 4^{\circ} \mathrm{W}\right)\end{array}$ & 6 & 13.5 & 1.23 & - & - & 0.15 & $\begin{array}{l}97^{\mathrm{g}} \\
(88-104)\end{array}$ & $\begin{array}{l}0.73 \\
(0.67-0.79)\end{array}$ & 6 & 2 & $\begin{array}{l}6 \\
(5-6)\end{array}$ \\
\hline \multicolumn{12}{|l|}{ North Atlantic } \\
\hline $\begin{array}{l}27 \text { Oct } 2009 \\
\left(25^{\circ} \mathrm{N} 40^{\circ} \mathrm{W}\right)\end{array}$ & 7 & 27.1 & 0.03 & 0.07 & $5.92 \pm 0.38$ & 0.14 & 154 & 1.3 & 5 & - & 11 \\
\hline$\left(24^{\circ} \mathrm{N} 40^{\circ} \mathrm{W}\right)$ & $7 \mathrm{a}$ & 27.2 & 0.07 & - & $5.29 \pm 0.35$ & 0.13 & 151 & 1.8 & 4 & - & 17 \\
\hline $\begin{array}{l}28 \text { Oct } 2009 \\
\left(23^{\circ} \mathrm{N} 41^{\circ} \mathrm{W}\right)\end{array}$ & 8 & 27.3 & 0.05 & 0.04 & $6.08 \pm 0.21$ & 0.19 & 226 & 0.61 & 15 & - & 4 \\
\hline $\begin{array}{l}29 \text { Oct } 2009 \\
\left(21^{\circ} \mathrm{N} 39^{\circ} \mathrm{W}\right)\end{array}$ & 9 & 27.4 & 0.09 & 0.10 & $7.41 \pm 0.29$ & 0.13 & 243 & 1.6 & 6 & - & 15 \\
\hline$\left(21^{\circ} \mathrm{N} 39^{\circ} \mathrm{W}\right)$ & $9 a$ & 27.4 & 0.10 & - & $7.75 \pm 0.98$ & 0.11 & 215 & 1.2 & 7 & & 13 \\
\hline $\begin{array}{l}30 \text { Oct } 2009 \\
\left(21^{\circ} \mathrm{N} 39^{\circ} \mathrm{W}\right)\end{array}$ & 10 & 27.4 & 0.06 & - & $7.16 \pm 0.59$ & 0.24 & 252 & 1.1 & 10 & - & 6 \\
\hline $\begin{array}{l}31 \text { Oct } 2009 \\
\left(19^{\circ} \mathrm{N} 38^{\circ} \mathrm{W}\right)\end{array}$ & 11 & 27.2 & 0.08 & 0.14 & $8.24 \pm 1.15$ & 0.16 & 278 & 0.86 & 13 & - & 6 \\
\hline$\left(18^{\circ} \mathrm{N} 37^{\circ} \mathrm{W}\right)$ & $11 \mathrm{a}$ & 27.3 & 0.11 & - & $8.28 \pm 0.70$ & 0.07 & 241 & 0.80 & 13 & - & 13 \\
\hline $\begin{array}{l}1 \text { Nov } 2009 \\
\left(17^{\circ} \mathrm{N} 36^{\circ} \mathrm{W}\right)\end{array}$ & 12 & 27.3 & 0.09 & 0.05 & $8.68 \pm 0.17$ & 0.24 & 296 & 1.2 & 10 & - & 6 \\
\hline$\left(16^{\circ} \mathrm{N} 35^{\circ} \mathrm{W}\right)$ & $12 \mathrm{a}$ & 27.4 & 0.11 & - & $7.55 \pm 0.21$ & 0.16 & 153 & 0.57 & 11 & - & 4 \\
\hline
\end{tabular}

${ }^{a}$ From Table $1 .{ }^{b}$ Methanol oxidation to $\mathrm{CO}_{2}$. Data in brackets show the minimum and maximum oxidation rates over a diel cycle and/or over the range in methanol concentrations used. $^{\mathrm{c}}$ Turnover times estimated from radiochemical experiments $\left(k^{-1}\right)$. ${ }^{\mathrm{d}}$ Methanol uptake into particles $(G)$ was not determined for stations $7-12 \mathrm{a}$. Values in brackets shows the minimum and maximum ratio determined over diel cycles sampling hourly, except for station 4 which shows variability over 3 days. e For diel stations $1-3$, methanol carbon contributing to BCD is calculated for every hour using the average methanol oxidation rates (using a methanol concentration of $241 \mathrm{nM}$ and in situ $k$ ) divided by the $\mathrm{BCD}$. The average methanol contribution to BCD over the diel experiment in then calculated. Values in brackets use the minimum and maximum methanol oxidation rates. For stations 4-12a, minimum and maximum contributions are calculated from the range in methanol oxidation rates found. ${ }^{\mathrm{f}}$ Methanol concentrations were not determined. Values for stations $1-3$ and 4-5 are based on the average surface concentrations measured between $16-25^{\circ} \mathrm{N}$ and $42-49^{\circ} \mathrm{N}$ respectively, during October/November 2009 transect of the Atlantic Ocean (AMT19, $n=6$ for both average values). $\mathrm{g}$ The concentration for station 6 is based on the average concentration determined at this station (L4) during May/June 2010 ( $n=4)$. Data in brackets show the minimum and maximum concentrations.

most of the carbon taken up by heterotrophic bacteria is probably respired and used for cell survival. Our average bacterial respiration of $0.23 \pm 0.15 \mu g \mathrm{Cl}^{-1} \mathrm{~h}^{-1}(n=16)$ compares favourably with the median open ocean value of $0.25 \mu \mathrm{gCl}^{-1} \mathrm{~h}^{-1}(n=105)$ in Robinson (2008), and with the range of $0.3 \pm 0.2 \mu \mathrm{gCl} l^{-1} \mathrm{~h}^{-1}$ for the subtropical Atlantic (Obernosterer et al., 2001). Our calculated average bacterial growth efficiency (BGE) of $0.03 \pm 0.01$ is low, but within the range reported in the literature (Alonso-Sáez et al., 2007; Morán et al., 2007; Robinson, 2008) and reflects the low availability of nutrients and DOC, and the high energetic costs associated with growth in central gyre locations. Our BGE of 0.02-0.04, typical of warm oligotrophic stations, implies that heterotrophic bacteria respire $96-98 \%$ of the assimilated carbon, which agrees with our methanol uptake results that $>99 \%$ of methanol in low chl water is respired and used as energy.

\subsubsection{Methanol contribution}

We wished to examine whether methanol could represent an important carbon source for marine bacteria, so we compared methanol oxidation rates with calculated BCD (Table 2). The largest contribution that methanol made to $\mathrm{BCD}$ was at station 1 , where it averaged $54 \%$. Maximum methanol contribution to BCD was shown either just before, or at dawn, and decreased through the day (data not shown). At the other oligotrophic gyre stations, methanol contributed on average $13 \%$ to BCD (Table 2). At the coastal station (L4) during summer when nutrients were depleted, average methanol contribution to BCD was also noteworthy at $6 \%$. 


\section{Discussion}

\subsection{Significance of methanol as a microbial carbon source}

When the average \% contribution of methanol to BCD is plotted against chl (Fig. 3) a statistically significant power relationship is found. This suggests that for chl $\geq 0.2 \mu \mathrm{g}{ }^{-1}$, methanol makes very little contribution to $\mathrm{BCD}$, presumably because there is enough organic carbon from phytoplankton to fuel their requirements. However, at chl $<0.2 \mu \mathrm{g} 1^{-1}$, when dissolved labile organic carbon from phytoplankton is likely to be low, bacteria look for alternative sources of organic molecules e.g. methanol and hence the contribution to $\mathrm{BCD}$ increases. We report the highest ever found surface methanol concentrations in the oligotrophic North Atlantic, which averaged of $221 \pm 52 \mathrm{nM}$ (between $16-25^{\circ} \mathrm{N}$, $n=10$ ), which compares to an average of $118 \pm 48 \mathrm{nM}$ found by Williams et al. (2004) in the Inter Tropical Conversion Zone at about $5-6^{\circ} \mathrm{N}$. These concentrations are also significantly higher than those reported in temperate North Atlantic and English Chanel waters of between $70-97 \mathrm{nM}$ by Dixon et al. (2011). In addition, there is some evidence to suggest that methanol concentrations are higher at pre-dawn (stations $7-12,242 \pm 50 \mathrm{nM}, n=6$ ), compared to solar noon (stations 7a, 9a, 11a, 12a, $190 \pm 45 \mathrm{nM}, n=4)$. However, microbial methanol turnover times for these oligotrophic stations (712a, Table 2) range between 4-15 days which is comparable to those found in coastal and shelf locations of this study and in Dixon et al. (2011) of between 7-33 days. This suggests that either there are a higher abundance of equally active methanol utilising microbes in the oligotrophic regions, or the microbes here have higher specific methanol uptake rates. Methylotrophic bacteria have to satisfy all their carbon and energy requirements with $\mathrm{C} 1$ compounds like methanol (Murrell and McDonald, 2000), and recent DNA sequencing from AMT samples has revealed that bacterial species like Methylophaga and Hyphomicrobium are commonly found throughout the Atlantic Ocean (S. Sargeant, personal communication, 2010), in addition to coastal locations (Neufeld et al., 2007, 2008; Giovannoni et al., 2008). Furthermore, Chistoserdova (2011) concluded that many organisms may typically use $\mathrm{C} 1$ compounds like methanol in co-metabolic pathways, which ecologically seems to make sense particularly in energy low environs like the oligotrophic gyres, where we now have evidence that methanol concentrations are several hundred nanomolar. Recent molecular findings have revealed that SAR11 Alphaprotoeobacteria, the most abundant heterotrophs in the oceans, have genome encoded pathways for the oxidation of $\mathrm{C} 1$ compounds, such as methanol, to produce energy only, and concluded that $\mathrm{C} 1$ oxidation might be a significant conduit by which dissolved organic carbon is recycled to $\mathrm{CO}_{2}$ in the upper ocean (Sun et al., 2011).
Dissolved organic carbon production by phytoplankton is believed to be the primary organic carbon source for marine bacteria. However previous results (e.g. López-Sandoval et al., 2011) have suggested that for oligotrophic waters, bacterial carbon demand often exceeds dissolved organic carbon produced by phytoplankton, indicating that additional sources are needed to sustain bacterial production in nutrient depleted areas. Our results suggest that under such conditions (low chlorophyll- $a$ and PP) methanol could be a significant organic carbon energy source for bacteria.

\subsection{Sources of methanol}

There are two likely sources of methanol, supply from the atmosphere via air/sea gas transfer and in-situ production. We used the $24 \mathrm{~h}$ mean rate of $E$ (Table 2), together with the daily mean depth of the surface mixed layer (data not shown), to calculate that a flux into the water column of between $2.5 \mathrm{mmol} \mathrm{m}^{-2} \mathrm{~d}^{-1}$ (Stn 1) and $130 \mu \mathrm{mol} \mathrm{m}^{-2} \mathrm{~d}^{-1}$ (Stn 2) is required to balance our measured loss rates. We calculated both the water-side film $\left(k_{\mathrm{w}}\right)$ and air-side transfer $\left(k_{\mathrm{a}}\right)$ via parameterisations with hourly wind speeds (Nightingale et al., 2000) at stations 1 and 2, recognising that the air-sea exchange of methanol is dominated by the $k_{\mathrm{a}}$ (Carpenter et al., 2004), as this gas is highly soluble. We have estimated net air to sea fluxes of only between 7.2 and $13 \mu \mathrm{mol} \mathrm{m}^{-2} \mathrm{~d}^{-1}$, by assuming that typical values of methanol in air and seawater were $1 \mathrm{ppb}$ (Jacob et al., 2005) and $100 \mathrm{nmoll}^{-1}$ (Williams et al., 2004), respectively.

The estimated contribution of air/sea gas transfer to the total biological loss of methanol therefore varied between a minimum of 0.2 and $1.1 \%$ and a maximum of $4 \%$ and $28 \%$ at stations 1 and 2, respectively. The range is caused by shallowing of the mixed layer in response to solar warming during the day, and deepening due to convective mixing in the night-time. We have assumed that rates of methanol uptake are uniform with depth at these stations. Our air-sea flux estimates are an order of magnitude lower than published estimates (Sinha et al., 2007; Millet et al., 2008) probably because winds were light $\left(3-5 \mathrm{~m} \mathrm{~s}^{-1}\right)$, and hence gas transfer rates were low at our stations.

Our flux calculations suggest that the atmosphere is unlikely to be a dominant source of methanol in the oligotrophic North Atlantic, which infers in-situ production in the ocean or lateral advection. Millet et al. (2008) concluded that, if methanol turnover was of the order of 3 days due to biotic consumption, then there must be a further oceanic source of $8 \times 10^{3} \mathrm{Tg} \mathrm{a}^{-1}$ in the mixed layer. Our novel observations of microbial turnover rates as low as 1 day, together with our high surface methanol concentrations of between 151-296 nM in 2009 strongly supports a large in situ oceanic methanol source. It is known that sunlight initiated reactions can decompose organic matter to form a variety of oxygenated chemicals (Zhou and Mopper, 1997), although direct evidence of methanol production from surface marine 


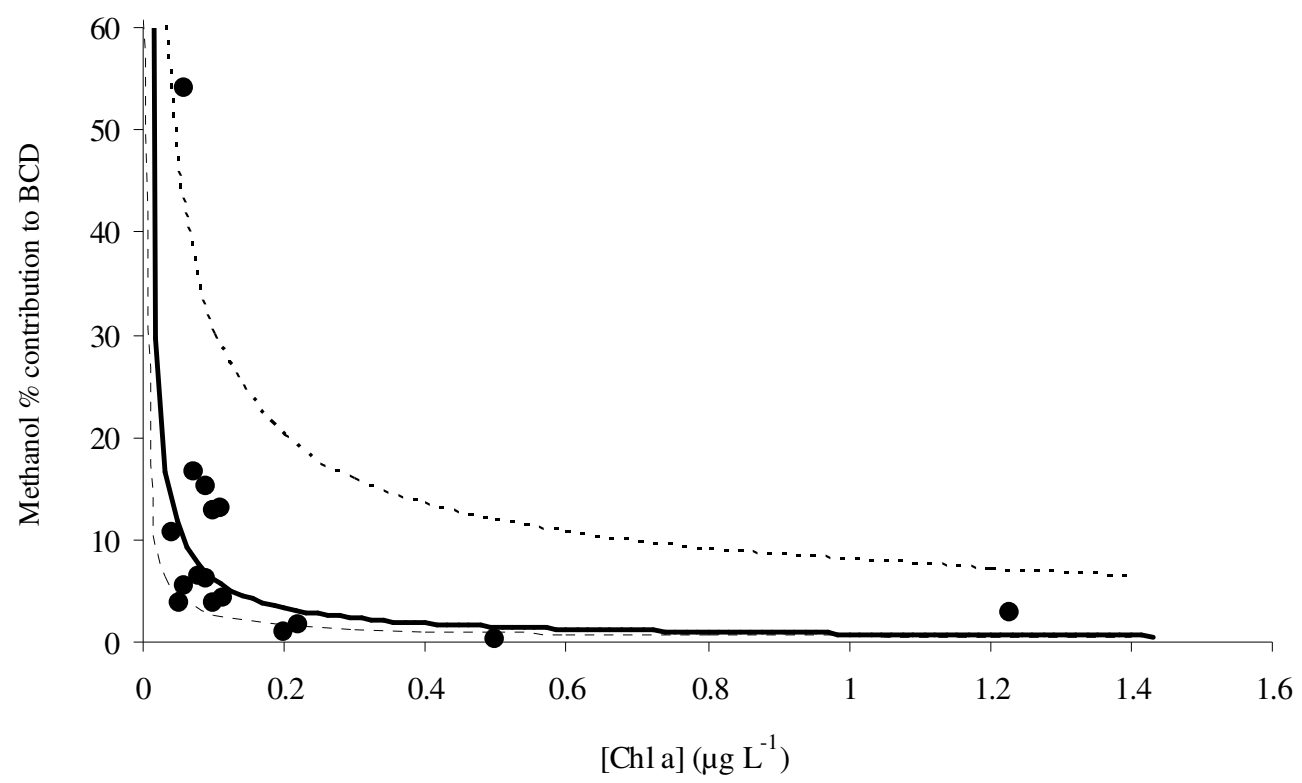

Fig. 3. Methanol contribution to $\mathrm{BCD}$ as a function of chlorophyll- $a$ concentration. The best fit of the data is given by $y=0.87 x^{-0.81}$ ( $n=16, r=0.640, P \geq 0.01$ ). The range shown by the dotted lines represent upper and lower limits calculated using the highest (if applicable) estimates of methanol oxidation rates divided by lowest estimates of BCD (calculated using $0.17 \mathrm{kgC} \mathrm{mol} \mathrm{leu}^{-1}$, Alonso-Sáez et al., 2007; Martínez-García et al., 2010), and the lowest rates of methanol oxidation (if applicable) divided by the maximum estimates of BCD (calculated using $1.55 \mathrm{kgC} \mathrm{mol} \mathrm{leu}^{-1}$, Simon and Azam, 1989), respectively.

dissolved organic matter is lacking. Heikes et al. (2002) suggest that abiotic methanol production in the oceans is minor, and propose bacterial transformations of algal carbohydrates (Sieburth and Keller, 1989) and production during phytoplankton growth as probable sources. However in the open ocean gyres, where we have measured the highest concentrations of methanol and highest microbial methanol oxidation rates, PP and chl are characteristically low, indicating that production by phytoplankton like diatoms, dinoflagellates etc. is not likely unless via the numerically dominant cyanobacteria present in these latitudes.

\section{Conclusions}

We show the highest ever reported microbial methanol oxidation rates (i.e. losses up to $6.1 \mathrm{nmol}^{-1} \mathrm{~h}^{-1}$ ) with concurrent concentrations of methanol up to $\sim 300 \mathrm{nM}$ for surface waters of the tropical North East Atlantic Ocean, resulting in biological turnover times as low as 1 day. These results suggest that methanol, and perhaps other OVOC compounds, represent a significant labile carbon source, particularly in nutrient deplete gyre systems. Our calculations suggest that methanol could significantly contribute to the energy requirements of the oligotrophic microbial community (Hoppe et al., 2002; Del Giorgio et al., 1997; Martínez-García et al., 2010), and could thus represent a proportion of the non phytoplankton derived sources of DOC often required to sustain bacterial production during oligotrophic regimes. But, contrary to cur- rent opinion (Dachs et al., 2005; Duarte et al., 2006), our results invoke in situ methanol production mechanisms (Millet et al., 2008), perhaps via photochemical degradation of dissolved organic carbon (Zhou and Mopper, 1997; Mopper et al., 1991) rather than air to sea transfer, as the dominant supply mechanism for methanol.

Acknowledgements. We thank P. Croot and C. Murell for their constructive advice on improving aspects of the manuscript. We also gratefully acknowledge E. M. S. Woodward, G. Tarran, D. Cummings, S. Sargeant, C. Widdicombe and the other scientists, captains, officers and crew of the (a) RRS Discovery for their help during the 2 UK SOLAS research cruises called DOGEE (Deep Ocean Gas Exchange Experiment) and INPSIRE (Investigation of the Near-surface Production of Iodocarbons-Rates and Exchanges) and (b) RRS James Cook for their help during AMT19. Satellite data were processed by the NERC Earth Observation Data Acquisition and Analysis Service (NEODAAS) at Plymouth Marine Laboratory (http://www.neodaas.ac.uk). This study was supported by the UK Natural Environmental Research Council (NERC) via UK SOLAS and Oceans 2025 funding for Plymouth Marine Laboratory.

All correspondence and requests for materials should be addressed to J. L. Dixon (jod@pml.ac.uk).

Edited by: G. Herndl 


\section{References}

Agustí, S., Duarte, C. M., Vaqué, D., Hein, M., Gasol, J. M., and Vidal, M.: Food-web structure and elemental (C, N and P) fluxes in the eastern tropical North Atlantic, Deep-Sea. Res. Pt. II, 48, 2295-2321, 2001.

Alonso-Sáez L., Gasol, J. M., Arístegui, J., Vilas, J. C., Vaqué, D., and Duarte, C. M.: Large scale variability in surface bacterial carbon demand and growth efficiency in the subtropical northeast Atlantic Ocean, Limnol. Oceanogr., 52, 533-546, 2007.

Barbosa, A. B., Galvão, H. M., Mendes, P. A., Álvarez-Salgado, X. A., Figueiras, F. G., and Joint. I.: Short-term variability of heterotrophic bacterioplankton during the upwelling off the NW Iberian margin, Prog. Oceanogr., 51, 339-359, 2001.

Beale, R., Liss, P. S., Dixon, J. L., and Nightingale, P. D.: Quantification of oxygenated volatile organic compounds (OVOCs) in seawater by membrane inlet-proton transfer reaction/mass spectrometry (MI-PTR/MS), Anal. Chim. Acta., in press, 2011.

Calvo-Díaz, A. and Morán, X. A. G.: Empirical leucine-to-carbon conversion factors for estimating heterotrophic bacterial production: Seasonality and predictability in a temperate coastal ecosystem, Appl. Environ. Microbiol., 75, 3216-3221, 2009.

Carpenter, L. J., Lewis, A., Hopkins, J. R., Read, K. A., Longley, I. D., and Gallagher, M. W.: Uptake of methanol to the North Atlantic Ocean surface, Global. Biogeochem. Cy., 18, GB4027, doi:10.1029/2004GB002294, 2004.

Chistoserdova, L.: Modularity of methylotrophy, revisited, Environ. Microbiol., doi:10.1111/j.1462-2920.2011.02464.x, in press, 2011.

Dachs, J. Calleja, M. L., Duarte, C. M., del Vento, S., Turpin, B., Polidori, A., Herndl, G. J., and Agustí, S.: High atmosphereocean exchange of organic carbon in the NE subtropical Atlantic, Geophys. Res. Lett., 32, L21807, doi:10.1029/2005GL023799, 2005.

Del Giorgio, P. A. and Cole, J. J.: Bacterial growth efficiency in natural aquatic systems, Annu. Rev. Ecol. Syst., 29, 503-541, 1998.

Del Giorgio, P. A., Cole, J. J., and Cimbleris, A.: Respiration rates in bacteria exceed phytoplankton production in unproductive aquatic systems, Nature, 385, 148-151, 1997.

Dixon, J. L.: Macro and micro nutrient limitation of microbial productivity in oligotrophic sub tropical Atlantic waters, Environ. Chem., 5, 135-142, 2008.

Dixon, J. L., Statham, P. J., Widdicombe, C. E., Jones, R. M., Barquero-Molina, S., Dickie, B., Nimmo, M., and Turley, C. M.: Cadmium uptake by marine micro-organisms in the English Channel and Celtic Sea, Aquat. Microb. Ecol., 44, 31-43, 2006.

Dixon, J. L., Beale, R., and Nightingale, P. D.: Microbial methanol uptake in northeast Atlantic waters, ISME J., 5, 704-716, 2011.

Duarte, C. M., Agustí, S., Arísttegui, J., González, N., and Anadón, R.: Evidence for a heterotrophic subtropical northeast Atlantic, Limnol. Oceanogr., 46, 425-428, 2001.

Duarte, C. M. Dachs, J., Llabrés, M., Alonso-Laita, P., Gasol, J. M., Tovar-Sánchez, A., Sanudo-Wilhemy, S., and Agustí, S.: Aerosol inputs enhance new production in the subtropical northeast Atlantic, J. Geophys. Res., 111, GB4006, doi:10.1029/2005JG000140, 2006.

Duncan, B. N., Logan, J. A., Bey, I., Megretskaia, I. A., Yantosca, R. M., Novelli, P. C., Jones, N. B., and Rinsland, C. P.: Global budget of CO, 1988-1997: Source estimate and vali- dation with a global model, J. Geophys. Res., 112, D22301, doi:10.1029/2007JD008459, 2007.

Galbally I. E. and Kirstine, W.: The production of methanol by flowering plants and the global cycle of methanol, J. Atmos. Chem., 43, 195-229, 2002.

Gasol, J. M., Vázquez-Domínguez, E., Vaqué, D., Agustí, S., and Duarte, C. M.: Bacterial activity and diffuse nutrient supply in the oligotrophic Central Atlantic Ocean, Aquat. Microb. Ecol., 56, 1-12, 2009.

Giovannoni, S. J., Hayakawa, D. H., Tripp, H. J., Sting, U., Givan, S. A., Cho, J.-C., Oh, H.-M., Kitner, J. B., Vergin, K. L., and Rappé, M. S.: The small genome of an abundant coastal ocean methylotroph, Environ. Microbiol., 10, 1771-1782, 2008.

Heikes, B. G., Chang, W., Pilson, M. E. Q., Swift, E., Singh, H. B., Guenther, A., Jacob, D. J., Field, B. D., Fall, R., Reimer, D., and Brand, L.: Atmospheric methanol budget and ocean implication, Global. Biogeochem. Cy., 16, 1133, doi:10.1029/2002GB001895, 2002.

Holm-Hansen, O., Lorenzen, C. J., Holmes, R. W., and Strickland, J. D. H.: Fluorometric determinations of chlorophyll, Journal du Conseil Permenant International pour l'Exploration de la Mer, 30, 3-15, 1965.

Hoppe, H.-G., Gocke, K., Koppe, R., and Begler, C.: Bacterial growth and primary production along a north-south transect of the Atlantic Ocean, Nature, 416, 168-171, 2002.

Jacob, D. J.: Chemistry of $\mathrm{OH}$ in remote clouds and its role in the production of formic acid and peroxymonosulfate, J. Geophys. Res., 91, 9807-9826, 1986.

Jacob, D. J., Field, B. D., Li, Q., Blake, D. R., de Gouw, J., Warneke, C., Hansel, A., Wisthaler, A., Singh, H. B., and Guenther, A.: Global budget of methanol: Constraints from atmospheric observations, J. Geophys. Res., 110, D08303, doi:10.1029/2004JD005172, 2005.

Joint, I. and Pomroy, A.: Phytoplankton biomass and production in the southern North Sea, Mar. Ecol.-Prog. Ser., 99, 169-182, 1993.

Kiene, R. P. and Hoffmann Williams, L. P.: Glycine betaine uptake, retention, and degradation by microorganisms in seawater, Limnol. Oceanogr., 43, 1592-1603, 1998

López-Sandoval, D. C., Fernández, A., and Marañón, E.: Dissolved and particulate primary production along a longitudinal gradient in the Mediterranean Sea, Biogeosciences, 8, 815-825, doi:10.5194/bg-8-815-2011, 2011.

López-Urrutia, Á. and Morán, X. A. G.: Resource limitation of bacterial production distorts the temperature dependence of oceanic carbon cycling, Ecology, 88, 817-822, 2007.

Mao, H., Talbot, R., Nielsen, and Sive, B.: Controls on methanol and acetone in marine and continental atmospheres, Geophys. Res. Lett., 33, L02803, doi:10.1029/2005GL024810, 2006.

Martínez-García, S., Fernández, E., Calvo-Díaz, A., Marañón, E., Morán, X. A. G., and Teira, E.: Response of heterotrophic and autotrophic microbial plankton to inorganic and organic inputs along a latitudinal transect in the Atlantic Ocean, Biogeosciences, 7, 1701-1713, doi:10.5194/bg-7-1701-2010, 2010.

Mary, I., Tarran, G. A., Warwick, P. E., Terry, M. J., Scanlan, D. J., Burkill, P. H., and Zubkov, M. V.: Light enhanced amino acid uptake by dominant bacterioplankton groups in surface waters of the Atlantic Ocean, FEMS Microbiol. Ecol., 63, 36-45, 2008.

Millet, D. B., Jacob, D. J., Custer, T. G., de Gouw, J. A., Goldstein, 
A. H., Karl, T., Singh, H. B., Sive, B. C., Talbot, R. W., Warneke, C., and Williams, J.: New constraints on terrestrial and oceanic sources of atmospheric methanol, Atmos. Chem. Phys., 8, 68876905, doi:10.5194/acp-8-6887-2008, 2008.

Mopper, K., Zhou, X., Kieber, R. J., Kieber, D. J., Sikorski, R. J., and Jones, R. D.: Photochemical degradation of dissolved organic carbon and its impact on the ocean carbon cycle, Nature, 353, 60-62, 1991.

Morán, X. A. G., Estrada, M., Gasol, J. M., and Pedrós-Alió, C.: Dissolved primary production and the strength of phytoplanktonbacterioplankton coupling in contrasting marine regions, Microb. Ecol., 44, 217-223, 2002.

Morán, X. A. G., Fernández, E., and Pérez, V.: Size-fractionated primary production, bacterial production and net community production in subtropical and tropical domains of the oligotrophic NE Atlantic in autumn, Mar. Ecol.-Prog. Ser., 274, 17-29, 2004.

Morán, X. A. G., Pérez, V., and Fernández, E.: Mismatch between community respiration and the contribution of heterotrophic bacteria in the NE Atlantic open ocean: What causes high respiration in oligotrophic waters?, J. Mar. Res., 65, 545-560, 2007.

Murrell, C. J. and McDonald, I. R.: Methylotrophy, in: Encyclopedia of Microbiology, edited by: Lederberg, J., vol. 3, Academic Press, 245-255, 2000.

Neufeld, J. D., Schäfer, H., Cox, M. J., Boden, R., McDonald, I. R., and Murrell, J. C.: Stable-isotope probming implicates Methylophaga spp abd novel Gammaproteobacteria in marine methanol and methylamine metabolism, ISME J., 1, 480-491, 2007.

Neufeld, J. D., Chen, Y., Dumont, M. G., and Murrell, C. J.: Marine methylotrophs revealed by stable-isotope probing, multiple displacement amplification and metagenomics, Environ. Microbiol., 10, 1526-1535, 2008.

Nightingale, P. D., Malin, G., Law, C. S., Watson, A. J., Liss, P. S., Liddicoat, M. I., Boutin, J., and Upstill-Goddard, R.: In situ evaluation of air-sea gas exchange parameterizations using novel conservative and volatile tracers, Global Biogeochem. Cy., 14, 373-387, 2000.

Obernosterer, I. P., Ruardij, P., and Herndl, G. J.: Spatial and diurnal dynamics of dissolved organic matter (DOM) fluorescence and $\mathrm{H}_{2} \mathrm{O}_{2}$ and the photochemical oxygen demand of surface water DOM across the subtropical Atlantic Ocean, Limnol. Oceanogr., 46, 632-643, 2001.

Robinson, C.: Heterotrophic bacterial respiration, in: Microbial Ecology of the Oceans, edited by: Kirchman, D. L., Wiley, New Jersey, 299-334, 2008.

Sieburth, J. M. and Keller, M. D.: Methylaminotrophic bacteria in xenic nanoalgal cultures: Incidence, significance, and role of nethylated algal osmoprotectants, Biol. Oceanogr., 6, 383-395, 1989.

Simon, M. and Azam, F.: Protein content and protein synthesis rates of planktonic marine bacteria, Mar. Ecol.-Prog. Ser., 51, 201213, 1989.
Singh, H. B. Chen, Y., Tabazadeh, A., Fukui, Y., Bey, I., Yantosca, R., Jacob, D., Arnold, F., Wohlfrom, K., Atlas, E., Flocke, F., Blake, D., Blake, N., Heikes, B., Snow, J., Talbot, R., Gregory, G., Sachse, G., Vay, S., and Kondo, Y.: Distribution and fate of selected oxygenated organic species in the troposphere and lower stratosphere over the Atlantic, J. Geophys. Res., 105, 3795-3805, 2000.

Singh, H. B., Chen, Y., Staudt, A., Jacob, D., Blake, D., Heikes, B., and Snow, J.: Evidence from the Pacific troposphere for large global sources of oxygenated organic compounds, Nature, 410, 1078-1081, 2001.

Singh, H. B., Tabazadeh, A., Evans, M. J., Field, B. D., Jacob, D. J, Sachse, G., Crawford, J. H., Shetter, R., and Brune, W. H.: Oxygenated volatile organic chemicals in the oceans: Inferences and implications based on atmospheric observations and air-sea exchange models, Geophys. Res. Lett., 30, 1862, doi:10.1029/2003GL017933, 2003.

Sinha, V., Williams, J., Meyerhöfer, M., Riebesell, U., Paulino, A. I., and Larsen, A.: Air-sea fluxes of methanol, acetone, acetaldehyde, isoprene and DMS from a Norwegian fjord following a phytoplankton bloom in a mesocosm experiment, Atmos. Chem. Phys., 7, 739-755, doi:10.5194/acp-7-739-2007, 2007.

Smith, D. C. and Azam, F.: A simple, economical method for measuring bacterial protein synthesis rates in seawater using ${ }^{3} \mathrm{H}-$ leucine, Mar. Microb. Food Webs, 6, 107-114, 1992.

Sun, J., Steindler, L., Thrash, J. C., Halsey, K. H., Smith, D. P., Carter, A. E., Landry, Z. C., and Giovannoni, S. J.: One carbon metabolism in SAR11 pelagic marine bacteria, PLoS ONE, 6, e23973, doi:10.1371/journal.pone.0023973, 2011.

Tie, X., Guenther, A., and Holland, E.: Biogenic methanol and its impacts on tropospheric oxidants, Geophys. Res. Lett., 30, 1881, doi:10.1029/2003GL017167, 2003.

Williams, J., Holzinger, R., Gros, V., Xu, X., Atlas, E., and Wallace, D. W. R.: Measurements of organic species in air and seawater from the topical Atlantic, Geophys. Res. Lett., 31, L23S06, doi:10.1029/2004GL020012, 2004.

Zhou, Z. and Mopper, K.: Photochemical production of lowmolecular weight carbonyl compounds in seawater and surface microlayer and their air-sea exchange, Mar. Chem., 56, 201-213, 1997.

Zubkov, M. V., Sleigh, M. A., and Burkill, P. H.: Heterotrophic bacterial turnover along the $20^{\circ} \mathrm{W}$ meridian between $59^{\circ} \mathrm{N}$ and $37^{\circ} \mathrm{N}$ in July 1996, Deep-Sea Res. Pt. II., 48, 987-1001, 2001.

Zubkov, M. V., Tarran, G. A., and Fuchs, B. M.: Depth related amino acid uptake by Prochorococcus cyanobacteria in the Southern Atlantic tropical gyre, FEMS Microbiol. Ecol., 50, 153-161, 2004. 